\title{
'A Whirlwind from the Puszta'. Hungarian and Hungarian Style Variety Acts in Berlin 1920-1961
}

\author{
Dániel Molnár \\ Independent researcher, Berlin, Germany
}

\begin{abstract}
Variety and revue shows played a significant role in popular culture during the first half of the $20^{\text {th }}$ century. Serving as a typical genre of cosmopolitan urban entertainment, these productions consisted of international acts, where a 'foreign' act was mostly defined by music, visual appearances and performance style; thus, not exclusively by the actual origin of the performer. This paper aims to analyze the presence and influence of Hungarian (style) acts in Berlin in three different socio-political contexts: the Weimar Republic, the NS-Zeit, and the Nachkriegszeit until the Berlin Wall was erected. Three large venues, the Plaza, the Scala and the Wintergarten (ca. 3000 seats each) defined the urban live entertainment sphere from 1920 onwards. These venues held shows until 1944. After the Second World War, only one large hall was opened in the destroyed city, the Friedrichstadt-Palast (in the Soviet occupation zone), which became a representative venue for East-Berlin as well as the GDR. The fact that Hungarian (style) acts were present in Berlin shows without a break during the entire research period shows that it did not depend on governmental cultural policies. The Hungarian show constituted a complex phenomenon which generated interest in the audience, guaranteeing their regular appearance. This analysis is based on primary sources; namely, a photography and programs collection housed at the Stadtmuseum Berlin. Moreover, Hungarian and German professional journals were utilized in this research.
\end{abstract}

Keywords: Berlin, entertainment, Hungarian themes, performance, show business, variety show

\section{INTRODUCTION}

The main purpose of this study is not to answer, but rather to raise a few questions regarding the role of national representations in show business. Entertainment productions, variety and revue shows are to date, not widely researched, despite the fact that before the era of transmitted entertainment (from the 1960s onwards: television and in current years, online video sites have taken their role) these productions were a significant and defining part of popular culture. Although the representatives of New Cultural History have already urged the analysis of these shows (GOETSCHEL - 
YON 2005:207), ${ }^{1}$ it still does not fall within the scope of either social history, or theatre studies in Europe. Ignoring these (traditionally low prestige) cultural phenomena, results in construing a distorted image of entertainment culture, regardless of the period. In this paper, I have attempted to collect and contextualize Hungarian-themed variety acts and references in major Berlin show venues; in specific, how frequently they appeared, and why, indeed, Hungarian themes were popular in variety shows.

\section{SOURCES AND METHODOLOGY}

The nature and definition of entertainment is rarely discussed. According to Richard Dyer's explanation, it is because entertainment is commonplace and seemingly everyone has a clear idea about it (DYER 2002:6). ${ }^{2}$ This field is organized around an external demand (BouRdiEu 1971:98), ${ }^{3}$ which is represented in the term 'show business' as well. Dyer states that:

"entertainment is a type of performance produced for profit, performed in front of a generalized
audience ('the public'), by a trained, paid group who do nothing else but produce performances
which have the sole (conscious) aim of providing pleasure." (DYER 2002:19)

The national identity of a performer is another problematic matter in the cosmopolitan entertainment business. We hardly have any personal records about the majority of performers (except press materials) and in many cases, we just suppose that they had a certain national identity. This raises a question of how we define national identity: for example in the practice of traditional circus families, it has not been a determining factor until this day. The nomadic lifestyle and the business driven marriages resulted in personalities deprived of it; or with multiple identities and mother tongues. In Berlin, the German language was used on a regular basis.

A circus or variety show usually consists of acts (German: Nummer). An act is an effective arrangement of skills (physical and/or personal) which generates interest in the public. Acts performed by foreigners always enjoyed a privilege in show compilations because of their temporary presence, visual or musical uniqueness, as well as their

1 "One of the recent contributions of cultural history is to extend the observation regarding nonconsecrated genres. Whether it is the theatre of mass consumption (generally called 'boulevard theater'), widely to study in the $20^{\text {th }}$ century, or other shows which are a part of dramatic arts, namely: music hall, dance, circus." German, Hungarian and French translations through the text are done by the author.

2 "Entertainment, show business, variety are not terms that are normally much thought about. (...) we all share a common-sense notion of what entertainment is. Yet precisely because it is such a final or absolute notion, it is very hard to define."

3 "a field of production which is organized around an external demand, socially and culturally inferior."

4 He also found that those who practice basically define it; this is not, however, the main issue of the paper: "Because entertainment is produced by professional entertainers, it is also largely defined by them. (...) none the less how it is defines, what it [entertainment] is assumed to be, is basically decided by those people responsible (paid) for providing it in concrete form. Professional entertainment is the dominant agency for defining what entertainment is." (DYER 2002:20) 
'exoticism' (COUTELET 2014:9). ${ }^{5}$ Diverging from the cultural traditions of the audience could have meant more possibilities to perform. Thus, most of the performers chose an international stage name. Many of them used a complete stage persona with a different cultural identity in order to make their act stand out (COUTELET 2014:10). ${ }^{6}$ Getting into show business never meant a straight career line (except for those who were born into a circus family); performers rarely had any kind of formal education and their acts were usually created by themselves. The producer or director of the show, in which the act appeared, could have made certain changes or adjustments such as costume, music or dramaturgy. The appearance of the stage persona of the performers mostly depended on their own understanding of the chosen cultural image; ethnographic accuracy was not necessarily among them. To provide just one example: the name of the 2 Collins (Elizabeth \& Martin Collins) does not recall any Hungarian associations, although the performers were a native Hungarian couple. They performed a Wild West or cowboy themed knife-throwing act. ${ }^{7}$ As the audience did not associate throwing knives at another person as a part of their image of Hungarians, they completely hid their real identity from the audience, indirectly (or even directly, by creating and promoting a false narrative about themselves) claiming a different origin. Therefore, artists utilized already existing images and stereotypes of certain cultures and also contributed to these through their own invention and fantasy. Imagination had its limits: the for-profit entertainment industry obviously did not allow elements that would conflict with existing stereotypes and the audience's horizon of expectations. As Coutelet remarks:

\footnotetext{
"Variety shows do not create stereotypes, they exploit them; they use the images forged by iconography, press and literature. Although sometimes it succeeds to create new exotic fashion like the tango, the cake walk, gypsy music or the black bottom."(COUTELET 2014:238).
}

Berlin, as a young metropolis, soon developed its theatre district along the Friedrichstraße at the end of the $19^{\text {th }}$ century. ${ }^{8}$ Apart from these theatres there were numerous other enterprises specialized in show production and entertainment: music halls, nightclubs, restaurants or other venues. I have narrowed my analysis to the largest music halls of the period (each had an auditorium of 3000 seats), namely the Wintergarten, ${ }^{9}$ the Scala, ${ }^{10}$

5 Coutelet found its origins in the 'abnormality' represented by them: “The 'foreign artists' who performed on the stage of the Folies Bergère originated from the success of the venue. Foreign [performers] presented an 'abnormality' to the public regarding values and cultural codes. Their 'different' body by their ethnic origin and/or their physical features through their extraordinary achievements immediately generate a feeling of strangeness which destabilize as much as fills with enthusiasm."

6 As Coutelet explains, the late $19^{\text {th }}$-century cosmopolitanisation of entertainment (she put the Parisian Folies Bergère in her focus) was an answer to the audience's requests for newer attractions.

7 Such acts were usually associated with the Middle East or the Wild West. As the film industry developed the Western genre, it became an almost exclusive theme for knife-throwing acts. Yet another interesting question to consider is: which themes were frequently used for the same type of physical acts?

8 See a comparison to London in PlatT et al. 2014:1-18.

9 1871-1944, Berlin NW Dorotheenstraße 38. A new venue at Potsdamer Straße was opened under the same name in 1992.

10 1920-1944, Berlin Martin-Luther-Straße 16. 
the Plaza ${ }^{11}$ prior to 1945 , and the Friedrichstadt-Palast after $1945 .{ }^{12}$ These music halls and their heritage are poorly researched in Germany (this is not to say that the state of research in Hungary differs considerably). Wolfgang Jansen gives a general, but rather futile impression of the Berlin music halls before World War II (JANSEN 1990); Jens Schnauber focuses on the 'Aryanization' of the Plaza and the Scala (SCHNAUBER 2002) in his monograph; Lothar Uebel's monograph is on the transformation of the former Küstriner Train Station, which became the Plaza in 1929; however, he did not analyze its productions (UEBeL 2011). Recently, a very general overview of the Berlin entertainments of the 1920s was written by Angelika Ret for the purpose of an exhibition catalogue (RET 2015). ${ }^{13}$

The following research is predominantly based on playbills from the Documenta artistica collection of the Stiftung Stadtmuseum Berlin. ${ }^{14}$ This is the largest public collection of documents related to Berlin entertainments, built on the Markschiessvan Trix ${ }^{15}$ Collection and the bequests of several other deceased private collectors, as well as artists. This is a solid base of sources (regarding its quantity and reliability) to create a list of the performances, which the reader will find in the following sections. ${ }^{16}$ The productions of the aforementioned four venues followed a simple pattern (more or less): split into two parts by an intermission, each consisting of 10 acts on average. Guest performances certainly had a different structure depending on the production. On average, 10 or 12 shows were produced per year and per venue (certainly depending on the success of shows, summer breaks as well as the audience's demand for something new). Smaller venues produced shows more frequently, every two weeks or in the case of certain nightclubs, even every night. ${ }^{17}$

The ephemeral nature of shows does not refer to research shows directly. However, a reconstructing analysis of the context, similar to what Patrice Pavis suggests in the case of dramatic text-based theatre performances (PAvIs 2003:20), is still possible. As most of the shows constitute a compilation of different acts (in fact, each of them can be considered as an independent show created by its performers), a special reconstructive analysis of each individual act is necessary. As the performers are completely unknown nowadays, further research constitutes an essential next step. This means not only extensive biographic research on each performer, but also, that it requires practical knowledge of each act and genre in order to fully understand their development and

1929-1944, Berlin Küstriner Platz 11.

12 Palast-Varieté 1945-1947, Friedrichstadt-Palast 1947 - still operating today.

13 French researchers published substantial works focusing on the last of Parisian revue theatres and their production creating practice in the last couple of years (Fourmaux 2009); the monograph by Nathalie Coutelet is likely the first attempt at analyzing actual productions of the Folies Bergère (COUTELET 2014).

14 I would like to thank the librarians and museum keepers for their kind help in my research. I am indebted most especially to Angelika Ret, the former referent of the Varieté, Circus and Cabaret Collection for her kindness and help.

15 Julius Markschiess-van Trix (1920-2017) was a collector of memorabilia (German and international artists) from 1945 onwards.

16 I included the production date of the show, the name of the act, as well as the genre of the act (if it was mentioned). I marked show or musical piece titles with italics. If two or more acts appeared in the same show, I separated them with a semicolon. I kept the original orthography of names.

17 For example, in 1938 the Faun Kabarett night club had a weekly playbill and show cycle. 
changes through a performer's career as well as in a particular show. I have already begun to collect and organize the surviving sources in an evolving database, but such detailed research could be conducted only as a long-term project.

\section{HUNGARIAN ACTS AT THE MAJOR BERLIN VENUES}

The Golden Twenties, 1920-1933

During this period, the majority of Hungarian style acts were a musical or dance act; the third largest group was comics. Hungarian comedians did not establish themselves in these music halls on a long term basis: The 3 Latabár ${ }^{18}$ appeared only once. Parallel to this, several comedians and comediennes of foreign origin made a career in Budapest music halls (Berta Türk, Gerard Laboch). However, in operetta and films several Hungarian actors and actresses (such as Gitta Alpár, Marika Rökk, Oszkár Dénes) found their way to the German entertainment business.

\section{PLAZA}

1929 February: Oscar Sabo, Sketch

1929 March: Paul Sandor, Zirkus-Burleske

1929 July: Nádasy-Baum, Tanzpaar

1929 October 8: Dobó Girls

1929 November: Vivat Hungaria von Camilla Linka, Marsch

1930 January: Franz Nádasy, Marcella Baum

1930 February: Vivat Hungaria; Paul Sandor

1930 June: Marche hongroise triomphale. Attila von J. Fucik

1930 July: Oscar Sabo

1930 November: Potpourri aus der Operette: Die lustige Witwe von Franz Lehár

1931 October: Gastspiel der Berliner Rotter-Bühnen: Gräfin Mariza. Operette von

Emmerich Kalman

1931 December 1-15: Der Graf von Luxemburg. Operette von Franz Lehàr. Original-

Inszenierung der Berliner Rotterbühnen

1932 March 1-15: Friederike. Operette von Franz Lehár

\section{SCALA}

1921 January: Pallay Anna mit Ballett

1921 September: Dobo Truppe

1923 November: Nádasi-Lieszkovszky Tanzpaar

1927 August: Janosky Trio

1929 September: Potpourri: Rendezvous bei Lehár. Paul Sándor

1931 June: Fantasie: Viktoria und ihr Husar von Paul Abraham

1932 May: Ungarische Phantasie von Debroy Somers

18 Kálmán Latabár Sr., Árpád Latabár, Kálmán Latabár Jr. were members of an esteemed Hungarian actors' dynasty - especially Kálmán Latabár Jr. (who starred in Hungarian comedy movies) is considered to be famous even in contemporary circles. 
1932 October: Barnabas von Geczy

1933 January: Ball im Savoy von Paul Abraham

\section{WINTERGARTEN}

1921 February: Janka von Kövesd, Pferde-Dressur

1922 May: Anni Gorilovich, Primaballerina der Staatsoper Budapest

1923 May: Magda Léna, Violinen-Virtuosin

1925 September: Drei Schwestern Kotányi, Klavier auf drei Klavieren

1928 March: The 3 Latabars, Parodie

1929 February: 8 Faludys, Akrobatik

1929 June: Hungaria-Truppe, Akrobaten

1929 September: Dajos Béla mit seinen Künstlern, Musik

1930 February: Marika Rökk, Tänzerin

1930 December: Agy Magyar, Tänzerin

1931 February: Ungarische Lustspiel-Ouverture von Keler Bela

1931 September: 2 Fokkers, Komik

1932 January: Hungaria Gipsy Girl, u.a. Lili Gyenes, Zigeunerorchester

1932 March: Schlußmarsch, Ungarische Lustspiel-Ouverture von Keler Bela

1932 July: Fortissimo aus Werken von Emmerich Kálmán

1932 December: Cervantes Truppe, Schleuderbrett.

\section{Nazi Germany, 1933-1944}

The Nazis restructured the German theatre system - including the music halls. The Reichstheaterkammer and its department of artists (Fachschaft Artistik) were under the control of the Ministry of Propaganda. In 1935, the Internationale Artisten Loge (the professional association of German artists) was disbanded due to 'counter-state activity'. Its professional journal, Das Programm, was banned. The staff moved to Zürich and launched a new weekly journal. ${ }^{19}$ As a substitute for Das Programm, the Reichstheaterkammer launched Die Deutsche Artistik. ${ }^{20}$ Jewish artists were excluded from shows and German artists were not allowed to choose American sounding names ${ }^{21}$ (apart from those who had already established themselves). The new state-controlled leisure organization Kraft durch Freude [Strength through joy] took over the Plaza in 1938. Although a reporter of the Hungarian professional journal, Artisták lapja [Artist's Journal, which included a German language section] considered Germany a problematic

19 The first issue was Organ des Varietés, Circus, Cabarets und Orchester-Ensembles published in Zürich, August 18, 1935.

20 Die Deutsche Artistik. First issue: Berlin, September 8, 1935. The fact that the paper did not include foreign language sections anymore, and that the typography was changed to Frakturschrift indicates that the new journal was supposed to serve primarily German artists instead of the international community.

21 Still, some exceptions were made. The artist Billy Jenkins 'the cowboy from Reinickendorf,' was considered 'half Jewish' (but a member of NSDAP). He wore an American stage name. He was the most popular cowboy in Germany at the time, being the hero of more than 200 cheap Wild West novels (ZAREMBA 2000). 
country, ${ }^{22}$ he still tried to keep informing his readers on the latest regulations concerning foreign workers. The political alliance between the Hungarian Kingdom and the Third Reich likely resolved these issues in the next years. In April of 1939, the Wintergarten put on a show (Varieté Festspiele) compiled of acts exclusively of the Reich's allies, presenting "the first line of German, Italian, Hungarian, Spanish, and Japanese artists." ${ }^{23}$ The outbreak of World War II limited the possibilities of artists in Europe. German music halls still demanded foreign acts, but these were exclusively limited to the political allies or the occupied lands..$^{24}$ The appearance of Hungarian acts became even more prevalent from 1941-1942, even though Hungary had also entered the war. As the 'total war' emerged, German theatres were closed in the already heavily damaged city in August of 1944. None of the three large music halls survived the siege of the city.

\section{PLAZA}

1939 January: Rolf Sandor

1939 May: Cervantes Truppe

1939 December: Die 7 aus Tokay - Wirbelwind aus der Puszta

1940 May: Lord

1940 October: Hungaria Truppe

1940 December: Sándor Károly Truppe

1941 October: Cervantes Truppe

1943 January: Linon

1943 May: 2 Buxtons

\section{SCALA}

1933 March:Ungarische Fantasie über die 2. Rhapsodie von Liszt für Jazzinstrumenten, Martin Roman

1934 January: Deszo Retter

1934 October: Barnabas von Geczy

1936 July: Deszo Retter

1937 October: Tibor von Halmay

1938 December: Deszo Retter

1939 June-July: Tilla Düring's ungarisches Puppen-Ballett

1940 January: Ferry Kowari

1941 September: 2 Allonso's, Equilibristik

1941 October: 2 Mihailovits, Step-Parodisten; Gerda Hunyadi, Tänzerin

1942 March: Zolnay u. Pleß, Wirbelwind-Tänzer

1942 April: Eve \& Partner, Akrobatik, Kautschuk

1942 June: 2 Fejes, Handakrobaten

22 "Since Germany is not suitable anymore for artists (impossibly low salaries, ban on currency export, the Aryan laws, and legal hazards) we can reckon only Western states with their weekly contracts." A magyar artistaság külföldi helyzete [Foreign situation of Hungarian artists]. Artisták lapja, 1937, 24 (November-December):3.

23 Stiftung Stadtmuseum Berlin, Documenta Artistica: monthly programme of Wintergarten, April 1939.

24 The data regarding this period is possibly more accurate since it was obligatory to indicate the proper country of origin of each act in the playbills - as an indicator of German superiority. 
1942 September: Emy und Lali Shugo, mondaines Tanzpaar

1942 October-November: Geschwister Szönyi, Tanzpaar. ${ }^{25}$

\section{WINTERGARTEN}

1933 March: Marcelle und Nádasy, Tanzpaar

1933 May: Vier Antaleks, Doppel-Antipodenspiele

1933 August: Ibolyka Zilzer, Violin-Virtuosin

1933 October: Sieben Tokayer, Akrobatik, Equilibristik

1934 March: Pfefferkuchen-Ballett, Volkstänze

1934 September: Viola Dobos, Tänzerin

1934 November: Lily Gyenes und ihre 20 Zigeunerinnen, Violin-Orchester

1934 December: Vier Antaleks, Fuß- u. Hochbalance

1935 March: Singing Fools (Stefan Simay, Olga Hites), Jazz-Parodisten

1935 May: Cervantes-Truppe, Luftakrobatik

1935 June: Dudus, Tänzerin

1935 July: Ferry Piroska, Tänzer

1935 November: Barnabas von Geczy mit Kammerorchester, Violin-Virtuose

1936 January: 24 Zigeunerbuben-Orchester

1936 June: Gizi Royko mit 12 Solistinnen, Violin-Virtuosin

1936 September: Jonny Langs Musikal-Mädels: "Weiber-Marsch" von Lehár; Ballett

Viktoria, Tänze

1936 December: Cervantes-Truppe, Schleuderbrett

1937 August: 2 Miko, Perche-Akt

1938 January: Sandor-Karoly, Kunstreiter

1938 April: Ouvertüre Wiener Frauen von Franz Lehár; Zolnay \& Plee, Tricktänzer

1938 June: Hungaria-Truppe, Ikarier, Fußakrobatik

1938 October: Rákóczy-Marsch; Hungaria-Ballett

1939 March: Mária Szántho, Tanz-Solistin; Puszta \& Comp. Tanz, Dressur, Akrobatik

1939 June: Rasko's ungarische Puli-Hunde, Dressur

1939 October 7: aus Tokay, ungarische Sektperlen, Tanz

1940 March: Sandor Karoly-Truppe, Kunstreiter

1940 May: Bàn Chöppi, Tanzakrobatin

1940 July 4: Misleys, Perche, Balance

1940 September: Margit Symo, Tänzerin; Linon, Clown auf dem Drahtseil

1940 October: Ric Joker, Getanzte Parodien; Bokara-Truppe, Schleuderbrett

1941 January 4: Patras, Akrobatik, Step

1941 March: Békeffy 4, Vokal-Quartett

1941 April: Ilonka und Sewald, Tanz und Musik

1941 October: Original-Trio-Mexicanos, Akrobatische Wurftanz

1941 September: Linon, Vagabund auf dem Bindfaden, Seil

${ }_{25}$ Ferenc Szőnyi (born in 1925, now François Szony) had a dance act with his sister, and after a successful career overseas, he has retired, now in the United States. I had a chance to interview him recently. He did not have memories of his early acts and career regarding Hungary or in Europe anymore. When he asked what is on in the Scala nowadays, I had to tell him that not long after their performance the theatre was bombed and raised to the ground. 
1942 January 3: Turuls, fliegendes Trapez

1942 May: Elizabeth und dell' Adami, Modernes Tanzpaar

1942 July: Florian's Schäferhunde, Dressur; Madika und ihre Tanzgruppe, Ballett;

Bokara-Truppe, Schleuderbrett

1942 August: Truppe Collins, Eine Cowboy-Fantasie

1942 November 2: Quick, Komponisten-Darsteller

1943 January: Christians Hunde, Dressur.

\section{Post-War Berlin and Budapest}

In August of 1945, Marion Spadoni (the daughter of artist and impresario Paul Spadoni, whose agency used to be among the largest in the city) managed to open a new venue close to the Friedrichstraße Station. She reopened the former Theater des Volkes (Theatre of the People which used to be Max Reinhardt's Großes Schauspielhaus earlier. Berlin, Am Zirkus 1. In 1984, a new building was erected under Friedrichstraße 107.) as the Palast-Varieté which was the only 3000-seat venue in the city, situated in the Soviet occupation zone. Two years later the venue was municipalized and a new manager, Nicola Lupo, was appointed. The Friedrichstadt-Palast became a representative venue of the newly formed German Democratic Republic (GDR) under his lead. He was suceeded in 1954 by Gottfried Hermann, who managed the venue until 1961. At the moment, only fragments of the institution's documentation are available for research. ${ }^{26}$

In Budapest, however, revues and variety shows were not favored by the Stalinist government at all. So-called revue experiments attempted to adapt these productions to the state-party system. Resultantly, foreign artists did not appear in variety shows during the $1951 / 1952$ and 1952/53 seasons. After 1949, the contracting policy of nationalized companies focused on the Eastern Bloc. Establishing a new professional network with other socialist countries was not an easy task: entertaining productions had low priority for the government bureaucracy and because of the Cold War's international atmosphere. This is why the 1951 summer season of the Municipal Grand Circus in Budapest dispensed foreign acts and artists. Although Hungarian circus literature claims that the lack of foreign attractions during this season was due to a boycott of Western agencies, it was the Hungarian government that ignored and denied the attempts of the circus management in contracting foreign artists (MoLNÁr 2018:204-205). In analyzing the reports of Echo (a renowned international artist's journal), we discover that the general interest of Western agencies was to keep Hungarian and other Eastern markets open for their clientele. Representative 'exchanges' of artists between Hungary and other socialist countries began from 1952 onwards, and the performers became a part of state representation during the next couple of years. ${ }^{27}$

26 Landesarchiv Berlin, C, Rep 727: Friedrichstadt-Palast, no 3; no 4.

27 As the original report stated: "The Trade Union, a deputy from the Ministry of People's Education, the management of the Municipal Grand Circus and its party organization bid farewell to the artists going abroad with the Circus. In his speech the speaker emphasized that the Hungarian artists can have foreign trips to fulfill their contracts thanks to the trust of our Party and government, and therefore they should be thankful to the liberating glorious Soviet Army, our Party and our beloved leader, Mátyás Rákosi." Szakszervezetek Központi Levéltára [Budapest, Central Archive of Trade Unions] XII. 40. f. 60\1952. ö. e.: Session report of the Artists’ Trade Union, September 5, 1952, p. 56. 


\section{PALAST-VARIETÉ 1945-1947, FRIEDRICHSTADT-PALAST 1947-1961}

1946 September: Palast-Ballet: Puszta

1949 June: Graziella; Die lustige Witwe-Tanzschau

1951 January: Hungaria-Truppe, Fußakrobatik

1953 June: Ferenc Pataki (?)

1953 September: Melodien aus der Operette: Die Csárdásfürstin

1954 March-April: Ballet-Revue: Die Csárdásfürstin. Zigeunerprimas: Lajos Héderváry

1955 October 5: Albatros

1956 January: Glück muss man haben

1956 April 2: Carlos, akrobatische Balancen

1958 April: Duo Pell, Handsprünge

1958 December 5: Albatros, Deutsch-ungarische Wurf-Sensation

1959 May 2: Ernesto, komische Exzentriker

1959 September 2: Orlóczi, Stirn-Perche Attraktion

1960 May: Budapester Melodie

1960 October: Duo Törös, akrobatisches Tanzpaar.

It seems that such drastic changes did not appear in Berlin during the same period; foreign acts and foreign references were still present in the Friedrichstadt-Palast shows (although they appeared less frequently than before). The management of the Friedrichstadt-Palast produced Hungarian acts and themes even when artists from Hungary were not allowed to leave their country. For example, the Hungaria-Truppe was a Hungarian themed, yet not Hungary-based act, which the management contracted for January of 1951. Knowing the Hungarian situation, we can suppose that the Friedrichstadt-Palast attempted to acquire Hungarian artists from Hungary too and they did not succeed. This also means that in spite of the efforts of the Hungarian government to control the state cultural representation both in the country and beyond: it was not successful. Another issue was Ferenc Pataki's (1921-2017) act, in June of 1953. He was a mental calculator, and he appeared on the cover of the Friedrichstadt-Palast's playbill. In the detailed program his act is crossed out with a pencil and corrected Holländisches Tanzpaar. An additional act is marked as Fred Feld. In the second example of the same playbill, he does not appear anymore - he was replaced by the dancers George Groke and Wladimir Marof. The reason is unknown; but it could have been an effect of the bureaucracy-driven controlling state systems. In 1954, a spectacular ballet version of Csárdáskirálynö [Princess Csárdás] was produced, just a couple of months before the opening night of the completely rewritten operetta in the Municipal Operetta Theatre in Budapest. ${ }^{28}$ In the 1956 production of Glück muss man haben [You must be lucky] two Hungarian roles appeared; although seemingly nobody was of Hungarian background among the creative team and the performers. The names of the characters, Iluschka and Papa Ferko, suggested that they were the simplest operetta-based Hungarian stock characters, and the Hungarian marriage party with Gulasch und Paprika also reinforced existing stereotypical images.

28 November 12, 1954. See its analysis in HeLtai 2011. 
After a caesura caused by the 1956 Revolution, at least two Hungarian themed acts appeared each year. Moreover, in 1960, the venue staged a completely Hungarian themed show - Budapester Melodie - in a co-production with Hungary (it is not specified in the playbill if it was the Hungarian Circus and Variety or another company). It credited Iván Szenes $^{29}$ as a writer, Ágnes Roboz ${ }^{30}$ as a choreographer, Anna Zentay ${ }^{31}$ as Marischka, the protagonist, and Béla Rácz ${ }^{32}$ and his gypsy orchestra as well as several other Hungarian acts - the rest of the creative team were regulars from the theatre. This show and its intercultural aspects (such as foreign operetta tours, which were used as a form of cultural diplomacy [HeLTAI 2004]) are still waiting for analysis. This indicates a very good official artistic relationship between the GDR and Hungary. The erection of the Berlin Wall a year later created a completely new situation for these relations. After 1961, the Friedrichstadt-Palast was looking for foreign professionals (most especially dancers) in particular, to fill up the ensemble after many members remained on the other side of the wall. The history of the Friedrichstadt-Palast's 'Hungarian dancer's colony' in the next couple of decades is still waiting to be told - alongside the story of the earlier music halls and their performers.

\section{WHY HUNGARIAN?}

An important question is: which features of national culture render it suitable for variety acts? Based on the iconographical-textual act descriptions of the playbills, ${ }^{33}$ the image of Hungarian culture rarely referred to the urban cultural context - it drew on rural, folk elements. ${ }^{34}$ A regular part of the narrative was the attributed 'national' landscape and landmarks, where Hungarian acts are claimed to have come from. The most frequently referenced places were Hortobágy, Tokaj, and the puszta (a desert) in general; and this narrative element did not change throughout the years. This was oftentimes linked to another rhetoric element, that the stage personas were descendants (Kinder) or rulers (Könige) of the referred lands. Whether they were kings or just simple children, paprika as the 'national' spice appeared in the blood or soul of performers. This metaphoric attribution was supposed to guarantee the uniqueness and temperament of the show.

29 Iván Szenes (1924-2010) was a Hungarian lyricist and writer; he also held the post of an artistic director at the Hungarian Circus and Variety Company between the years 1956-1961.

30 Ágnes Roboz (born in 1926) is a Hungarian choreographer and ballet teacher. Member of the Budapest Operetta Theatre between the years 1950 and 1956; folk dance teacher at the Hungarian Dance Academy until 1971. She collaborated with Emöke Pöstényi choreographing another Friedrichstadt-Palast production, Heiss und Kalt in 1974.

31 Anna Zentay (1924-2017) was a Hungarian actress and member of the Budapest Operetta Theatre between the years 1950-1979.

32 Béla Rácz (1899-1962) was a Gypsy violinist (prímás) and composer.

33 The descriptions were mostly compiled by the acts themselves or their agents; and possibly edited by the management of the theatre or the producer of the show.

34 Despite the fact that the Budapest city nightlife and entertainment reached worldwide interest and importance by the end of the 1930s (MolnáR 2017). 


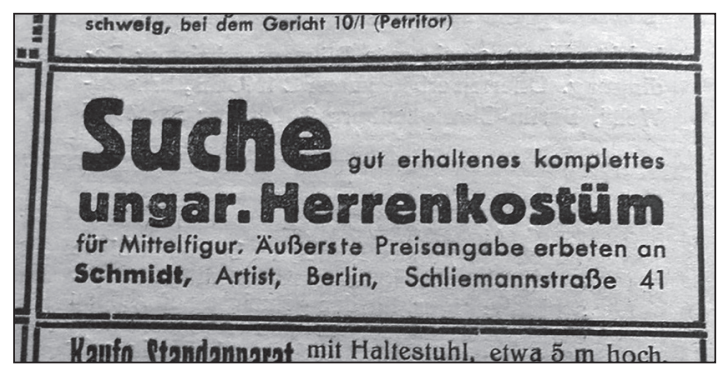

Figure 1. Artist looking for a Hungarian costume in an advertisement. Artisten-Welt, Berlin, 1941 (March 9)
Those acts, which did not use such folk-based narratives and stage personas, emphasized that their talent was already praised by other institutions. $^{35}$

Visually, the most important feature was the costume (Fig. 1; Fig. 2). Hungarian national costumes had a distinctive visual style - not only the national colors, but especially the cut of female dresses - are easily recognizable and spectacular. Also, it was not difficult to copy or imitate. Original folk wear was rare, as it was expensive and would not have worked well on stage. Stage costumes had to be adapted for the stage persona; but most importantly, for the act itself. These were working clothes. The performer had to be able to perform his act in the costume; so regardless of what original folk dresses looked like, alterations (adding extra pockets, adjusting length, changing sleeve design) was necessary. ${ }^{36}$ Apart from the visual side of performance, music could be another decisive factor in an act or show. The characteristic and distinctive Hungarian national musical style was commonly known in Europe for many years prior. In an 1895 edition of the professional journal Der Artist, a production entitled Original Rozsika Horwath was advertised as the "first Hungarian-German soubrette." 37 Hungarian and/or Gypsy musicians frequently appeared in the shows, playing not just folk tunes or classical pieces; but contemporary musical styles as well. ${ }^{38}$ In the $1920 \mathrm{~s}$ and 1930s (also known as the Silver Age of operetta) composers of Hungarian origin or those that identified as Hungarians (just to mention Imre Kálmán, Franz Lehár, Paul Abraham) played a significant role in German-speaking musical theatre before $1945 .{ }^{39}$ Alongside the music, the 'national' dance, the csárdás, was regularly used as it was

35 For example, Ferenc Nádasi and his partner's dance act were advertised as the "soloists of the Hungarian Royal Opera". Despite the fact that they were working in first class music halls all over Germany for many years, mentioning the Hungarian Opera, seemed to be more profitable for them.

36 See an analysis of stage costume cuts in Hungarian revues (MolnáR 2018:355).

37 Der Artist. Central-Organ der Circus, Varietébühnen und reisenden Theater, 1895 no 508 (Nov 4). This ad was placed only one year after the opening of the first permanent music hall in Budapest, the Somossy Orfeum (now the Budapest Operetta Theatre). Her declared half-Hungarian stage persona indicates that the Hungarian theme already appeared at the beginning of institutionalized urban entertainment.

38 Especially if it used folk-inspired tunes and melodies. Barnabás von Géczy and his orchestra held the position of the house orchestra of the Berlin Hotel Esplanade, but appeared three times between 1932-1935 in the Scala and the Wintergarten. His hit song Puszta-Fox was even recorded in Swedish by Zarah Leander.

39 One can certainly argue how a potpourri from Lehár's The Merry Widow directly influenced the audience's image of Hungarian culture; but as the act's stage context could have had such references (sets, or it was simply mentioned in the introduction), I decided to include them in the list above. 


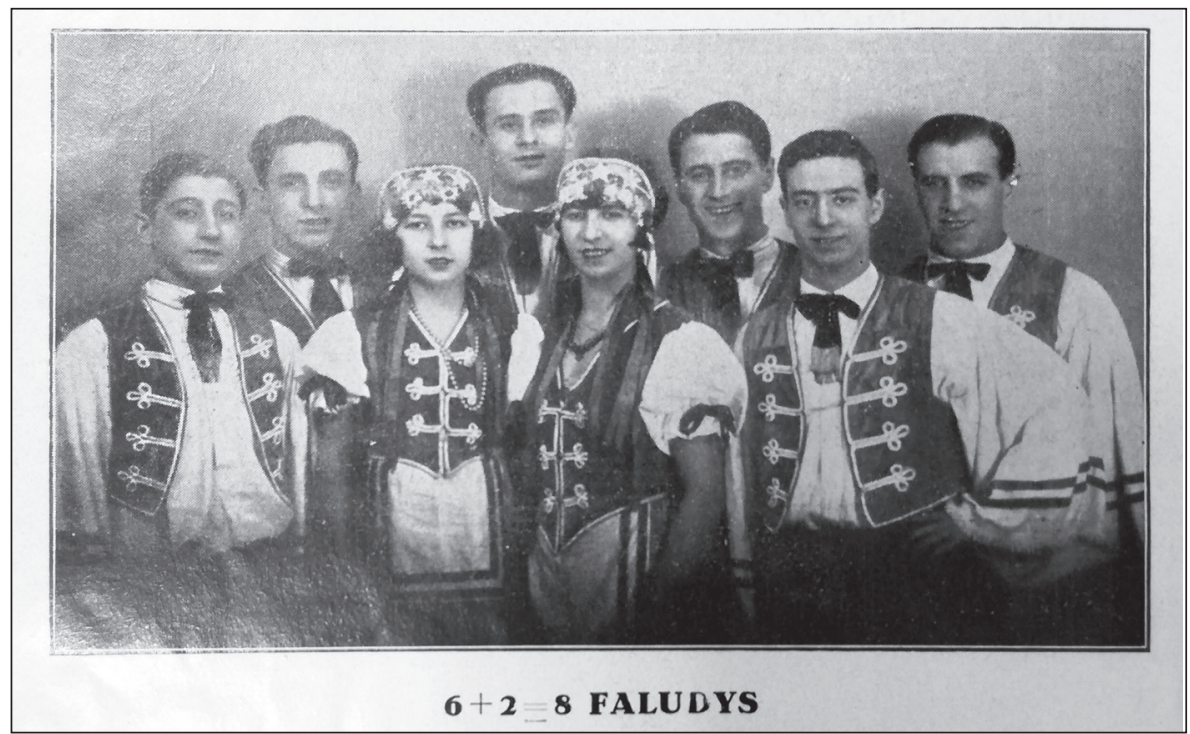

Figure 2. The 8 Faludys acrobatic act in the playbill of the Wintergarten, February 1929. Stiftung Stadtmuseum Berlin, Documenta Artistica

already popularized by hit operettas, like the Zigeunerbaron or Princess Csárdás. ${ }^{40} \mathrm{~A}$ 'national' animal was also occasionally a part of this image. Nevertheless, horse acts rarely appeared in music halls because they required space and appropriate infrastructure (a circus is more suitable for such acts).$^{41}$ Although Hungarian dog breeds such as the puli have a characteristic appearance, and they are easy to train, it was not as popular of an act genre as teeterboard acts. ${ }^{42}$ Teeterboards (Schleuderbrett) are not an integrated part of the Hungarian national stereotype, yet despite this, Hungarian artists developed this kind of act. ${ }^{43}$ Moreover, they are still considered to be the most typical Hungarian act. ${ }^{44}$ The Hungarian theme in such acts is more than just an appearance; it pays homage to original entrepreneurs.

${ }_{40}$ In the second half of the 1930s, folk-inspired dance and show productions were produced not only for foreign tours, but for Budapest music halls and nightclubs as well. See the reconstruction of this trend in the entertainment industry in Budapest (MolnáR 2018:353).

${ }^{41}$ One of the classic horse acts is called Ungarische Post [Hungarian Post]: The performer leads several horses on standing two other horses.

42 See Rasko's puli dogs in the Wintergarten, June 1939. Compare this with African or Indian themed acts where elephants are attached to their cultural image. Note, that this is not suitable for a music hall performance.

43 The 8 Faludys' teeterboard act was already considered as an old genre in 1929, the one "which does not become obsolete and cannot be overtaken by the young". 'Father and master' Sigis Faludy established the act in 1891. Stiftung Stadtmuseum Berlin, Documenta Artistica: Playbill of Wintergarten, February 1929.

44 See its technical description and differences comparing to the Korean teeterboard in FEDEC 2009:16. 
The features of the Hungarian image described above were rather static. However, a deeper analysis would be necessary to prove it. ${ }^{45}$ This image consisted of many layers: visual, musical, and even the sense of taste was stimulated (through the dishes or spices referenced above); maybe this complex experience was among the reasons why Hungarian was a recurring theme element in variety shows. The visual/musical complexity of the Hungarian image might have assured its frequency as many different genres could have appeared under the same theme. The fact that the Hungarian theme regularly appeared in differential socio-political contexts through the ages indicates that the Berlin audience had a general interest towards it, which did not depend on governmental cultural policies or political alliances.

There are still many unanswered questions, not only those regarding the representation of Hungarian culture. Was Hungarian the most popular cultural representation in variety shows? What kinds of elements were used to represent it? Were these visual or musical references also present in the case of representations of other cultures? How many of the aforementioned performers were really native Hungarians? Perhaps we will be able to answer these questions within the next few years, and in the meantime, let us hope that entertainment will find a solid place in the agenda of academic researchers.

\section{REFERENCES CITED}

Bourdieu, Pierre

1971 Le marché des biens symboliques. L'année sociologique. Troisième série 22:49-126.

Coutelet, Nathalie

2014 Étranges artistes sur la scène des Folies Bergère (1871-1936). Paris: Presses

DYER, Richard Universitaires de Vincennes.

2002 Only entertainment. London and New York: Routledge.

FEDEC

2009 Teeterboard. Basic Circus Arts Instruction Manual. Chapter 9.

Available online: http://www.fedec.eu/file/242/download (accessed: January, 2019).

FouRMAUx, Francine

2009 Belles de Paris. Une ethnologie du music-hall. Paris: Éditions du comité des travaux historiques et scientifiques.

Goetschel, Pascale - Yon, Jean-Claude

2005 L'histoire du spectacle vivant: un nouveau champ pour l'histoire culturelle? In Martin, Laurent - Venayre, Sylvain (eds.) L'Histoire culturelle du contemporain, 193-220. Paris: Nouveau Monde.

45 An example of extension could be the appearance of Lake Balaton (Plattensee) as a referred landmark in the narratives from the 1970s; this area became a popular destination for German tourists. 
HeLtaI, Gyöngyi

2004 Operett diplomácia. A Csárdáskirálynő a Szovjetunióban 1955-56 fordulóján [Operetta Diplomacy. The Princess Csárdás in Moscow and Leningrad 19551956]. Aetas 20(3-4):87-118.

2011 Usages de l'opérette pendant le période socialiste en Hongrie (1949-1968). Budapest: Atelier - Centre Franco-hongrois en sciences sociales.

JANSEN, Wolfgang

1990 Das Varieté. Die glanzvolle Geschichte einer unterhaltenden Kunst. Beiträge zu Theater, Film und Fernsehen aus dem Institut für Theaterwissenschaft der Freien Universität Berlin. 5. Berlin: Hentrich.

Molnár Dániel

2017 Müvészi elgondolás: Miss Arizona és Rozsnyai Sándor. Az Arizona Revue Dancing müsora és hatáskeltő elemei, 1932-1944 [Artistic Concept: Miss Arizona and Sándor Rozsnyai. The Shows and Effects of Arizona Revue Dancing, 1932-1944]. Replika 1-2:89-118.

2018 Vörös csillagok. A Rákosi-korszak szórakoztatóipara és a szocialista revük [Red Stars. Entertainment Business during Hungarian Stalinism and the Socialist Revues]. Budapest: Ráció.

Pavis, Patrice

2003 Elöadáselemzés [Analyzing Performance. Theater Dance and Film]. Budapest: Balassi.

Perault, Sylvie

2010 Une approche ethnologique du costume de spectacle. Du port aux savoirfaire - Des revues parisiennes aux planches des théâtres. Place: Éditions universitaires européennes.

Platt, Len - Becker, Tobias -Linton, David (eds.)

2014 Popular Musical Theatre in London and Berlin, 1890-1939. Cambridge: Cambridge University Press.

RET, Angelika

2015 Salto mit dem Kopf voraus. In BARTMAn, Dominik (ed.) Tanz auf dem Vulkan. Das Berlin der Zwanziger Jahre im Spiegel der Künste, 93-98. Berlin: Verlag $\mathrm{M}$ im Stadtmuseum Berlin.

SCHNAUBER, Jens

2002 Die Arisierung der Scala und Plaza. Varieté und Dresdner Bank in der NSZeit. Kleine Schriften der Gesellschaft für unterhaltende Bühnenkunst, Band 8. Berlin: Weidler.

UEBEL, Lother

2011 Eisenbahner, Artisten und Zeitungsmacher. Zur Geschichte des ehemaligen Küstriner Bahnhofs. Grundstückgesellschaft Franz-Mehring-Platz $1 \mathrm{mbH}$.

ZAREMBA, Michael

2000 Billy Jenkins - Mensch und Legende. Ein Artistenleben. Husum Hansa Verlag. 


\section{ARCHIVES}

Berlin

Landesarchiv Berlin, C, Rep 727: Friedrichstadt-Palast, no 3; no 4.

Stiftung Stadtmuseum Berlin, Documenta Artistica.

Budapest

Szakszervezetek Központi Levéltára [Budapest, Central Archive of Trade Unions]. XII. 40. f. $60 \backslash 1952$. Ö. e.: Session report of the Artists' Trade Union, 5 September 1952, p. 56.

Dániel Molnár is a theatre historian based in Berlin focusing on theatre entertainment in Central Europe. After working for several years as an artist, he obtained a clown degree in 2005 and a PhD in history (2017). He curated three exhibitions about the former Budapest nightlife. In February 2019 Red Stars - Entertainment business during Hungarian Stalinism and the socialist revues opened in the National Széchényi Library in Budapest. The exhibition is accompanied by a monography under the same title. E-mail: danielmolnarphd@gmail.com 